\title{
Mechanisms involved in the vasorelaxant effects produced by the acute application of amfepramone in vitro to rat aortic rings
}

\author{
J.S. López-Canales ${ }^{1,2}$, J. Lozano-Cuenca², E. Muñoz-Islas², J.C. Aguilar-Carrasco² \\ O.A. López-Canales ${ }^{1}$, R.M. López-Mayorga ${ }^{1}$, E.F. Castillo-Henkel ${ }^{1}$, \\ I. Valencia-Hernández ${ }^{1}$ and C. Castillo-Henkel ${ }^{1 \dagger}$
}

${ }^{1}$ Section of Postgraduate Studies and Investigation, Higher School of Medicine from the National Polytechnic Institute, Mexico City, Mexico ${ }^{2}$ Department of Cellular Biology, National Institute of Perinatology, Mexico City, Mexico

\begin{abstract}
Amfepramone (diethylpropion) is an appetite-suppressant drug used for the treatment of overweight and obesity. It has been suggested that the systemic and central activity of amfepramone produces cardiovascular effects such as transient ischemic attacks and primary pulmonary hypertension. However, it is not known whether amfepramone produces immediate vascular effects when applied in vitro to rat aortic rings and, if so, what mechanisms may be involved. We analyzed the effect of amfepramone on phenylephrine-precontracted rat aortic rings with or without endothelium and the influence of inhibitors or blockers on this effect. Amfepramone produced a concentration-dependent vasorelaxation in phenylephrine-precontracted rat aortic rings that was not affected by the vehicle, atropine, 4-AP, glibenclamide, indomethacin, clotrimazole, or cycloheximide. The vasorelaxant effect of amfepramone was significantly attenuated by NG-nitro-L-arginine methyl ester (L-NAME) and tetraethylammonium (TEA), and was blocked by removal of the vascular endothelium. These results suggest that amfepramone had a direct vasorelaxant effect on phenylephrine-precontracted rat aortic rings, and that inhibition of endothelial nitric oxide synthase and the opening of $\mathrm{Ca}^{2+}$-activated $\mathrm{K}^{+}$channels were involved in this effect.
\end{abstract}

Key words: Cardiovascular pharmacology; Amfepramone; Obesity; Rat aorta; Nitric oxide; Potassium channels

\section{Introduction}

Obesity is a major health problem associated with the lifestyle of modern society worldwide. It has been linked to cardiovascular disease, dyslipidemia, osteoarthritis, diabetes mellitus, cancer, and decreased longevity $(1,2)$. Dietary changes and increased exercise are essential steps to counter this relatively recent tendency towards obesity. However, patients who are obese or overweight may also benefit from pharmacological therapy (2).

Currently, appetite-suppressant drugs, pancreatic lipase inhibitors, thermogenic agents and dietetic products are indicated for the treatment of obesity (3). Because adverse effects are associated with some antiobesity drugs (4), new drugs are urgently needed. Among the cardiovascular complications of appetite-suppressant drugs are hypertension, tachycardia, arrhythmias, valvular regurgitation and myocardial infarction (5-7). The mechanisms of these adverse effects include their serotonergic agonist properties, their activity as combined norepinephrine and serotonin reuptake inhibitors in the peripheral and central autonomic system, and their ability to stimulate catecholamine release (6-9).

Amfepramone is as appetite-suppressant drug used for the treatment of overweight and obesity. Clinical evidence suggests that adverse reactions to oral amfepramone include cardiovascular effects such as transient ischemic attacks and primary pulmonary hypertension $(10,11)$. These clinical observations are in line with experimental studies in which amfepramone administered intravenously to dogs produced $i$ ) a transient vasodepressor effect, followed by a vasopressor effect (12); ii) a dose-related depressor reaction (13); and iii) a marked pressor response when administered intracerebroventricularly (13). Increasing evidence suggests that systemic and central administration of amfepramone produces a number of different cardiovascular effects. Bispo

Correspondence: J.S. López-Canales: <skiold666@hotmail.com>.

${ }^{\dagger}$ In memoriam.

Received July 22, 2014. Accepted December 11, 2014. First published online March 27, 2015. 
da Silva and Cordellini (14) found that treatment with amfepramone in vivo caused hyporeactivity to noradrenaline in the aorta, which was abolished by both endothelium removal and the presence of NG-nitro-L-arginine methyl ester (L-NAME), suggesting a role for nitric oxide (NO) in the vascular effects of amfepramone. To the best of our knowledge, the immediate vascular effects of amfepramone when applied in vitro to rat aortic rings and the mechanisms of its effects have not been evaluated. Therefore, the present study aimed to analyze the effect of amfepramone on phenylephrine-precontracted rat aortic rings with or without endothelium. The influence of $10^{-6} \mathrm{M}$ atropine, $10^{-5} \mathrm{M} \mathrm{L}$ NAME, $10^{-2} \mathrm{M}$ tetraethylammonium (TEA), $10^{-3} \mathrm{M} 4-\mathrm{AP}$, $3.1 \times 10^{-7} \mathrm{M}$ glibenclamide, $10^{-5} \mathrm{M}$ indomethacin, $10^{-5} \mathrm{M}$ clotrimazole, and $10^{-5} \mathrm{M}$ cycloheximide on the effects of amfepramone was also evaluated.

\section{Material and Methods}

\section{Animals}

Experiments were performed on isolated thoracic aortic rings of adult male Wistar rats (body weight 250-300 g). Rats $(n=23)$ were purchased from the bioterium of the Escuela Superior de Medicina (México City). Animals were housed in plastic cages in a special temperature-controlled room $\left(22 \pm 2^{\circ} \mathrm{C}, 50 \%\right.$ humidity) on a $12: 12 \mathrm{~h}$ light/dark cycle (lights on at 7:00 am). The study was approved by the Animal Care Committee of the Escuela Superior de Medicina; the protocol was in agreement with the 1986 Animals (Scientific Procedures) Act of the British Parliament (http://www.legislation.gov.uk/ukpga/1986/14/contents, accessed February 10, 2015).

\section{Preparation of aortic rings}

Animals were euthanized by decapitation, and the aortas were immediately excised and placed in cold buffer before being cleaned and freed from surrounding connective tissue. The isolated arteries were cut into rings 4$5 \mathrm{~mm}$ long and placed in $10 \mathrm{~mL}$ tissue chambers filled with Krebs-Henseleit bicarbonate buffer (118 mM NaCl; $4.7 \mathrm{mM}$ $\mathrm{KCl} ; 1.2 \mathrm{mM} \mathrm{KH} \mathrm{PO}_{4} ; 1.2 \mathrm{mM} \mathrm{MgSO} 4.7 \mathrm{H}_{2} \mathrm{O} ; 2.5 \mathrm{mM}$ $\mathrm{CaCl}_{2} \cdot 2 \mathrm{H}_{2} \mathrm{O} ; 25 \mathrm{mM} \mathrm{NaHCO} ; 11.7 \mathrm{mM}$ dextrose, and $0.026 \mathrm{mM}$ calcium disodium EDTA). In some experiments the $\mathrm{KCl}$ concentration was increased to $80 \mathrm{mM}$ and the $\mathrm{Na}^{+}$concentration reduced to maintain osmotic equilibrium. Tissue baths, maintained at $37^{\circ} \mathrm{C}$ and $\mathrm{pH} 7.4$, were bubbled with a mixture of $95 \% \mathrm{O}_{2}$ and $5 \% \mathrm{CO}_{2}$.

To record isometric tension, aortic rings were mounted on two stainless steel hooks, one fixed to the bottom of the chamber and the other to a BIOPAC TSD125C-50g force transducer connected to a BIOPAC MP100A-CE data acquisition system (BIOPAC Systems, Inc., USA). The optimal tension, determined by preliminary experiments, was that which gave the greatest response to phenylephrine $\left(10^{-6} \mathrm{M}\right)$. Initially, a tension of $2 \mathrm{~g}(100 \%)$ was applied, and rings were allowed to equilibrate for $2 \mathrm{~h}$. Thirty minutes after setting up the organ bath, contractile responses were tested with $10^{-6} \mathrm{M}$ phenylephrine. Endothelium-denuded aortic strips were prepared by turning the rings gently several times on the distal portion of small forceps. Endothelial integrity was pharmacologically assessed by acetylcholine-induced vasodilatation $\left(10^{-6} \mathrm{M}\right)$. Segments that did not relax in response to acetylcholine were considered to be endothelium-denuded. After exposure to $10^{-6} \mathrm{M}$ phenylephrine or $10^{-6} \mathrm{M}$ acetylcholine, tissues were rinsed three times with Krebs solution to restore basal tension.

\section{Drugs}

All drugs except amfepramone, which was a generous gift from Productos Medix, Sociedad Anónima de Capital Variable (Mexico), were purchased from Sigma-Aldrich Co. (USA). All compounds were dissolved in distilled water. Fresh solutions were prepared for each experiment.

\section{Experimental protocol}

First set of experiments. Thirty minutes after the restoration of basal tension (see Preparation of aortic rings), $10^{-9}$ $10^{-5} \mathrm{M}$ amfepramone and $10^{-9}-10^{-5} \mathrm{M}$ acetylcholine, a positive control of vasorelaxation, were cumulatively added to intact rat aortic rings. Acetylcholine was added at intervals of approximately 2 min and amfepramone was added at intervals of approximately $10 \mathrm{~min}$. Tension was expressed as a percentage of basal contraction $(2.0 \pm 0.16 \mathrm{~g}, 100 \%)$.

Second set of experiments. Thirty minutes after restoration of basal tension (see Preparation of aortic rings), $10^{-6}$ $\mathrm{M}$ phenylephrine was added to rat aortic rings with or without endothelium, which elicited a steady contraction after $20 \mathrm{~min}$. Thirty minutes after adding phenylephrine, $10^{-9}-10^{-5} \mathrm{M}$ amfepramone and $10^{-9}-10^{-5} \mathrm{M}$ acetylcholine, a positive control of vasorelaxation, were cumulatively added. Acetylcholine was added at intervals of approximately 3 min and amfepramone was added at intervals of approximately $20 \mathrm{~min}$. Tension was expressed as a percentage of phenylephrine-induced contraction $(3.54 \pm 0.25 \mathrm{~g}$, $100 \%)$.

Third set of experiments. Since amfepramone induced moderate concentration-dependent vasorelaxation on phenylephrine-precontracted rat aortic segments, an attempt was made to determine the mechanisms involved in this relaxant effect. Thirty minutes after adding $10^{-6} \mathrm{M}$ phenylephrine (see Second set of experiments), aortic rings with endothelium were preincubated for $30 \mathrm{~min}$ with various compounds in order to explore the mechanisms involved in the relaxant effect induced by amfepramone on precontracted rat aortic rings. The compounds used for preincubation were: $i$ ) the vehicle (distilled water); ii) $10^{-6} \mathrm{M}$ atropine, a competitive muscarinic acetylcholine receptor antagonist; iii) $10^{\mathrm{v} 5} \mathrm{M}$ L-NAME, a direct inhibitor of NO synthase; iv) $10^{-2}$ $\mathrm{M}$ TEA, a $\mathrm{Ca}^{2+}$-activated $\mathrm{K}^{+}$channel blocker and nonspecific voltage-activated $\mathrm{K}^{+}$channel blocker; v) $10^{-3} \mathrm{M}$ 4-aminopyridine (4-AP), a voltage-activated $\mathrm{K}^{+}$channel blocker; vi) $3.1 \times 10^{-7} \mathrm{M}$ glibenclamide, an ATP-sensitive 
$\mathrm{K}^{+}$channel blocker, ( $\mathrm{K}_{\mathrm{ATP}}$ ); vii) $10^{-5} \mathrm{M}$ indomethacin, a prostaglandin synthesis inhibitor; viii) $10^{-5} \mathrm{M}$ clotrimazole, a cytochrome P450 inhibitor; and ix) $10^{-5} \mathrm{M}$ cycloheximide, a general protein synthesis inhibitor. After preincubation, the influence of vehicle and drugs on the vasorelaxant response to $10^{-9}-10^{-5} \mathrm{M}$ amfepramone was tested.

\section{Data analysis and statistics}

Data are reported as means $\pm \mathrm{SE}$. In all experiments, aortic segments were obtained from six animals. Statistical analysis was performed in two main data sets. In the first set, the vasorelaxant effects of amfepramone and acetylcholine on aortic rings, whether intact or precontracted with phenylephrine, were analyzed using a one-way repeated-measures analysis of variance (ANOVA). In the second set, the effects of endothelium, antagonist, inhibitors and blockers on the relaxant effect of amfepramone on phenylephrine-precontracted aortic segments were analyzed using a two-way repeated-measures ANOVA. Each analysis of variance was followed by the Student-NewmanKeuls post hoc test. Statistical significance was considered as $\mathrm{P}<0.05$ (15). The statistical analysis was performed with the SigmaPlot 12 program (Systat Software Inc., USA).

\section{Results}

\section{Effect of amfepramone and acetylcholine on rat aortic rings}

Figure 1 shows the effects of the cumulative addition of $10^{-9}-10^{-5} \mathrm{M}$ amfepramone and $10^{-9}-10^{-5} \mathrm{M}$ acetylcholine on intact rat aortic rings. Amfepramone and acetylcholine produced moderate concentration-dependent vasorelaxation in those aortic segments. The $\log \mathrm{EC}_{50}$ values for

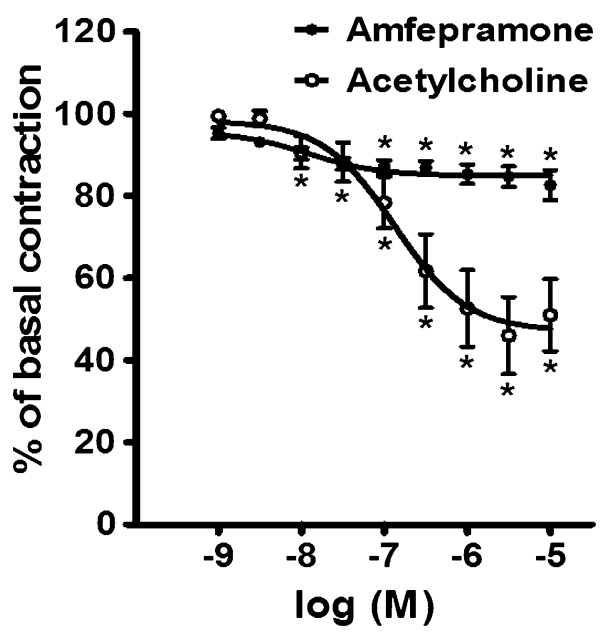

Figure 1. Concentration-dependent relaxation of $10^{-9}-10^{-5} \mathrm{M}$ amfepramone (closed circles) and $10^{-9}-10^{-5} \mathrm{M}$ acetylcholine (open circles) in rat aortic rings with intact endothelium. Data are reported as means \pm SE of $n=6$ observations. ${ }^{*} P<0.05$ vs basal contraction (two-way ANOVA). amfepramone- and acetylcholine-induced vasorelaxation were -7.91 and $-6.87 \mathrm{M}$, respectively. Following the addition of amfepramone and acetylcholine, the maximum vasorelaxation $\left(E_{\max }\right)$ was $17.34 \pm 3.66 \%$ and $48.98 \pm 8.75 \%$ of basal contraction, respectively. The vasodilator response produced by amfepramone appeared immediately on the addition of each concentration of this drug and reached a maximum value after $5 \mathrm{~min}$. This vasodilator response was sustained and continued without change.

\section{Effect of amfepramone and acetylcholine on} phenylephrine-precontracted rat aortic rings with and without endothelium

Figure 2 shows the effects of the cumulative addition of $10^{-9}-10^{-5} \mathrm{M}$ amfepramone and $10^{-9}-10^{-5} \mathrm{M}$ acetylcholine on phenylephrine-precontracted rat aortic rings with and without endothelium. Amfepramone and acetylcholine elicited a concentration-dependent relaxation on aortic rings with intact endothelium, an effect that was blocked by the functional removal of the endothelium. The $\log \mathrm{EC}_{50}$ of amfepramone and acetylcholine for vasorelaxation in aortic rings with intact endothelium was $-6.04 \mathrm{M}$ and $-7.67 \mathrm{M}$, respectively. The maximum vasorelaxation produced by amfepramone and acetylcholine in aortic rings with intact endothelium was $69.63 \pm 5.53 \%$ and $98.51 \pm 0.94 \%$, respectively. The vasorelaxant response produced by amfepramone appeared immediately on the addition of each concentration of this drug and reached a maximum value after $15 \mathrm{~min}$. This vasorelaxant response was sustained and continued without change.

\section{Effect of atropine on the relaxant effect induced by} amfepramone on phenylephrine-precontracted rat aortic rings

Figure 3 shows the effect of $10^{-6} \mathrm{M}$ atropine on the vasorelaxation induced by $10^{-9}-10^{-5} \mathrm{M}$ amfepramone on phenylephrine-precontracted rat aortic rings. The maximum vasorelaxant effect produced by amfepramone was unaffected by the absence $(86.65 \pm 3.40 \%)$ or presence $(90.72 \pm 2.58 \%)$ of atropine.

Effect of L-NAME, TEA, 4-AP and glibenclamide on the relaxant effect induced by amfepramone on phenylephrine-precontracted rat aortic rings

Figure 4 shows the effect of the vehicle $(A), 10^{-5} \mathrm{M} \mathrm{L}$ $\operatorname{NAME}(B), 10^{-2} \mathrm{M}$ TEA $(C), 10^{-3} \mathrm{M} 4-\mathrm{AP}(D)$, and $3.1 \times 10^{-7}$ $M$ glibenclamide $(E)$ on the vasorelaxation induced by $10^{-9}$. $10^{-5} \mathrm{M}$ amfepramone on phenylephrine-precontracted rat aortic rings. The maximum vasorelaxant effect produced by amfepramone was unaffected by the absence (74.63 \pm $5.25 \%)$ or presence $(83.35 \pm 6.28 \%)$ of the distilled water vehicle and two other pretreatments: 4-AP (90.82 $\pm 2.47 \%$ vs $86.42 \pm 4.79 \%$ ), and glibenclamide (93.10 $\pm 2.73 \%$ vs $85.95 \pm 3.35 \%)$. The maximum vasorelaxant effect produced by amfepramone was significantly $(P<0.05)$ attenuated in the presence vs absence of two compounds: 


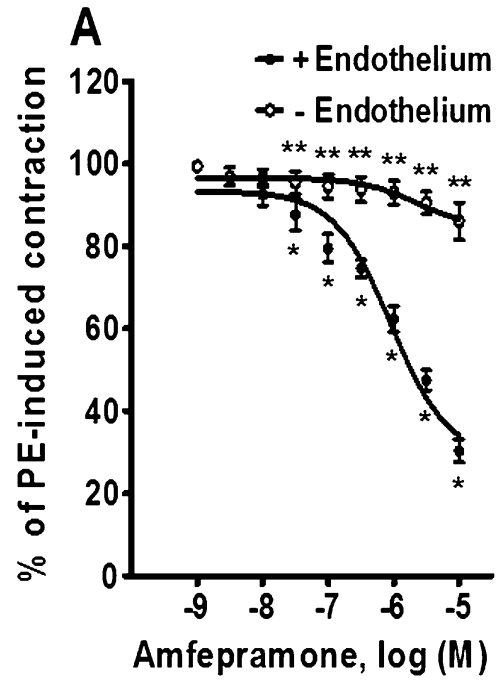

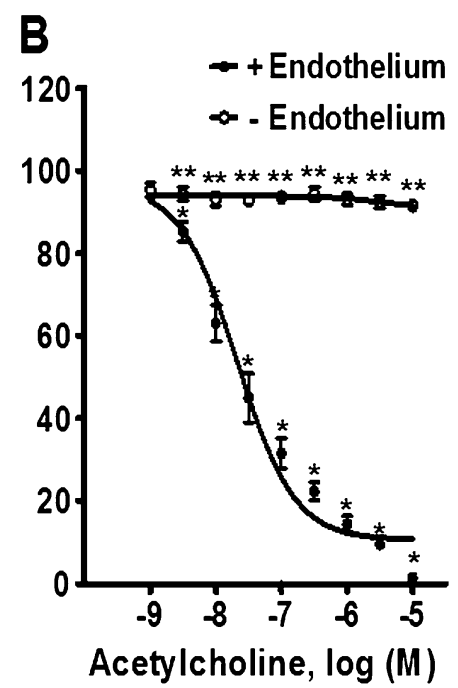

Figure 2. Concentration-dependent relaxation of $10^{-9}-10^{-5} \mathrm{M}$ amfepramone $(A)$ and $10^{-9}-10^{-5} \mathrm{M}$ acetylcholine $(B)$ in $10^{-6} \mathrm{M}$ phenylephrine (PE) precontracted rat aortic rings with (closed circles) and without (open circles) endothelium. Data are reported as means $\pm S E$ of $n=6$ observations. ${ }^{*} \mathrm{P}<0.05$ vs basal phenylephrine-induced contraction; ${ }^{* *} \mathrm{P}<0.05$ vs rings with endothelium (two-way ANOVA).
L-NAME $(16.50 \pm 1.39 \%$ vs $86.32 \pm 3.36 \%)$ and TEA $(24.84 \pm 3.55 \%$ vs $79.93 \pm 3.94 \%)$.

\section{Effect of indomethacin and clotrimazole on the relaxant effect induced by amfepramone on phenylephrine-precontracted rat aortic rings}

Figure 5 shows the effect of $10^{-5} \mathrm{M}$ indomethacin on the relaxation induced by $10^{-9}-10^{-5} \mathrm{M}$ amfepramone on phenylephrine-precontracted rat aortic rings. The maximum vasorelaxant effect produced by amfepramone was unaffected by the presence or absence of indomethacin

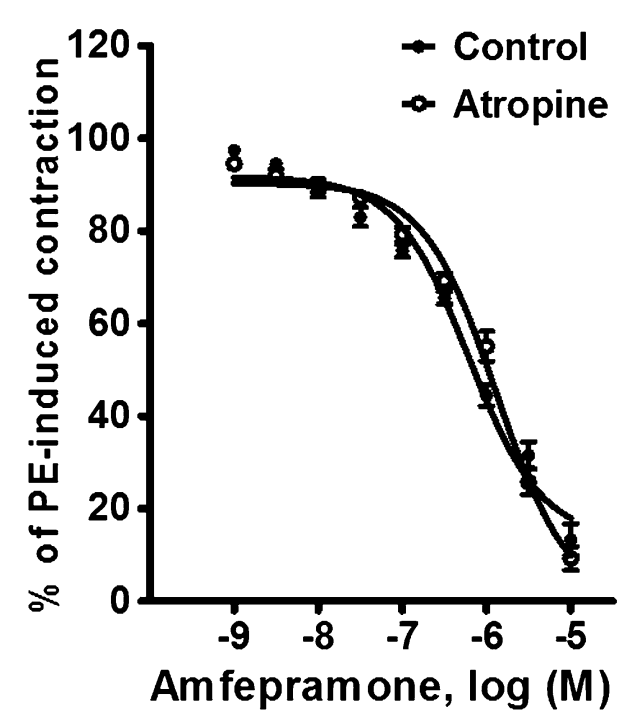

Figure 3. Effects of $10^{-6} \mathrm{M}$ atropine on amfepramone-induced vasorelaxation in rat aortic rings with functional endothelium and precontracted with $10^{-6} \mathrm{M}$ phenylephrine (PE). Data are reported as means $\pm S E$ of $n=6$ observations. $P>0.05$ vs control (two-way repeated-measures ANOVA).
$(75.16 \pm 5.09 \%$ vs $83.16 \pm 6.69 \%)$ or clotrimazole $(95.62 \pm$ $1.36 \%$ vs $90.34 \pm 3.09 \%)$.

Effect of cycloheximide on the relaxant effect induced by amfepramone on phenylephrine-precontracted rat aortic rings

Figure 6 shows the effect of $10^{-5} \mathrm{M}$ cycloheximide on the relaxation induced by $10^{-9}-10^{-5} \mathrm{M}$ amfepramone on phenylephrine-precontracted rat aortic rings. The maximum vasorelaxant effect produced by amfepramone was unaffected by the presence $(95.08 \pm 1.54 \%)$ or absence $(93.12 \pm 2.37 \%)$ of cycloheximide.

\section{Discussion}

The vasorelaxation produced by amfepramone on phenylephrine-precontracted rat aortic rings was: i) unaffected by vehicle, atropine, 4-AP, glibenclamide, indomethacin, clotrimazole and cycloheximide; ii) significantly attenuated by L-NAME and TEA; and iii) blocked by removal of the endothelium. These results suggest that the relaxant effect elicited by amfepramone on phenylephrine-precontracted rat aortic rings involved the inhibition of endothelial nitric oxide synthase and the opening of $\mathrm{Ca}^{2+}$-activated $\mathrm{K}^{+}$channels.

\section{Effect of amfepramone and acetylcholine on rat aortic rings}

Amfepramone and acetylcholine produced moderate, dose-dependent vasorelaxant responses in aortic rings with intact endothelium (Figure 1). The direct vasorelaxant effects produced in aortic rings by amfepramone reinforces the aforementioned findings of previous studies in dogs, in which the intravenous administration of amfepramone produced a dose-dependent depressor reaction (13) and a transient vasodepressor effect (12). However, the marked pressor response to intracerebroventricular administration of amfepramone (13), and the transient vasodepressor 


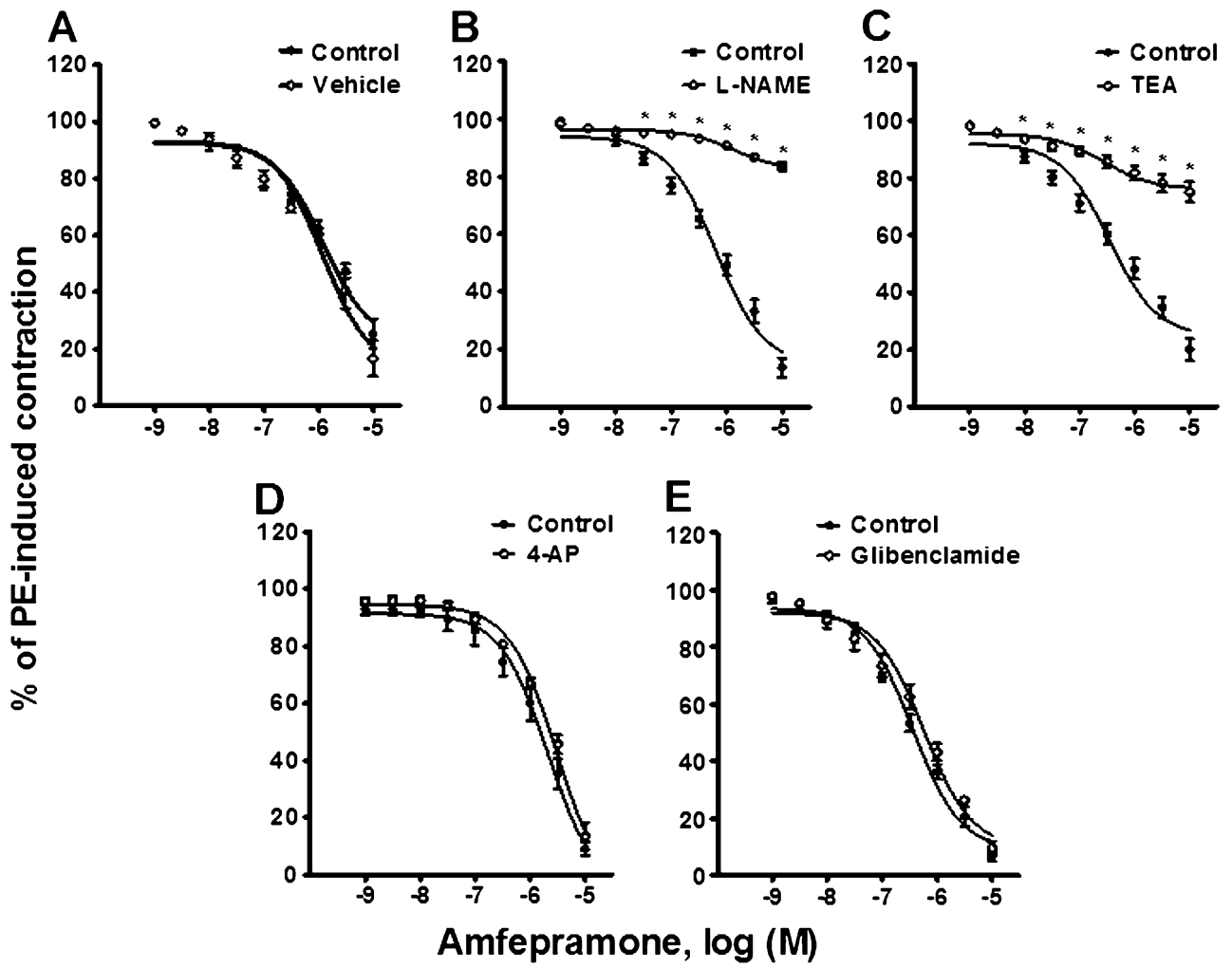

Figure 4. Amfepramone-induced vasorelaxation in rat aortic rings with functional endothelium and precontracted with $10^{-6} \mathrm{M}$ phenylephrine (PE). Effects of preincubation with: $A$, Vehicle (the distilled water control), $B, 10^{-5} \mathrm{M} \mathrm{L-NG-nitroarginine} \mathrm{methyl} \mathrm{ester} \mathrm{(L-}$ NAME), $C, 10^{-2} \mathrm{M}$ tetraethylammonium (TEA), $D, 10^{-3} \mathrm{M} 4$-aminopyridine (4-AP) and $E, 3.1 \times 10^{-7} \mathrm{M}$ glibenclamide. Data are reported as means \pm SE of $n=6$ observations. ${ }^{*} \mathrm{P}<0.05$ vs control (two-way repeated-measures ANOVA).

effect produced by intravenous amfepramone, followed by a vasopressor effect (12), differ from our results as well as from the other results in those studies. Moreover, the vasorelaxant responses produced by amfepramone in aortic rings are not consistent with a clinical study in which oral administration of amfepramone produced ischemic attacks in the brain of an obese patient (11).
Discrepancies in the reported vascular effects of amfepramone may be related to differences in experimental conditions as well as routes of administration, because: $i$ ) the systemic (intravenous or oral) administration of amfepramone has been associated with transient vasodepressor and vasopressor responses in humans and dogs (11-13); ii) the central (intracerebroventricular) administration of
A

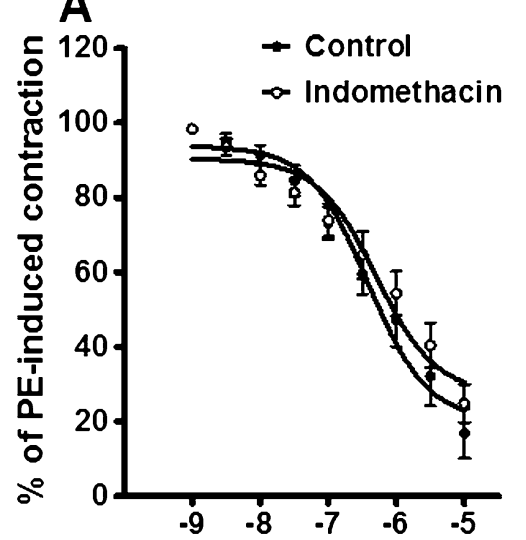

B

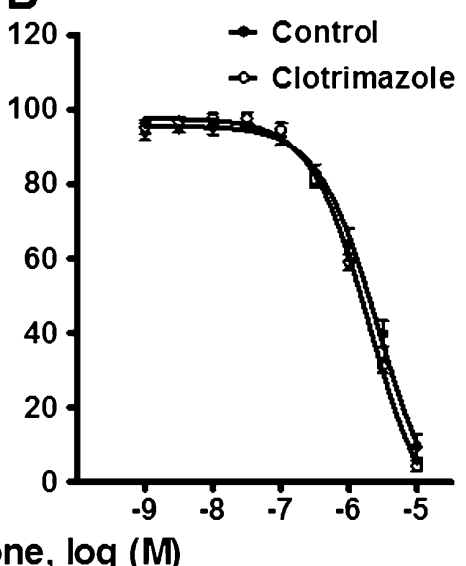

Figure 5. Effects of $10^{-5} \mathrm{M}$ indomethacin $(A)$ and $10^{-5} \mathrm{M}$ clotrimazole $(B)$ on amfepramoneinduced vasorelaxation in rat aortic rings with functional endothelium and precontracted with $10^{-6} \mathrm{M}$ phenylephrine (PE). Data are reported as means \pm SE of $n=6$ observations. $P>0.05$ vs control (two-way repeated-measures ANOVA). 


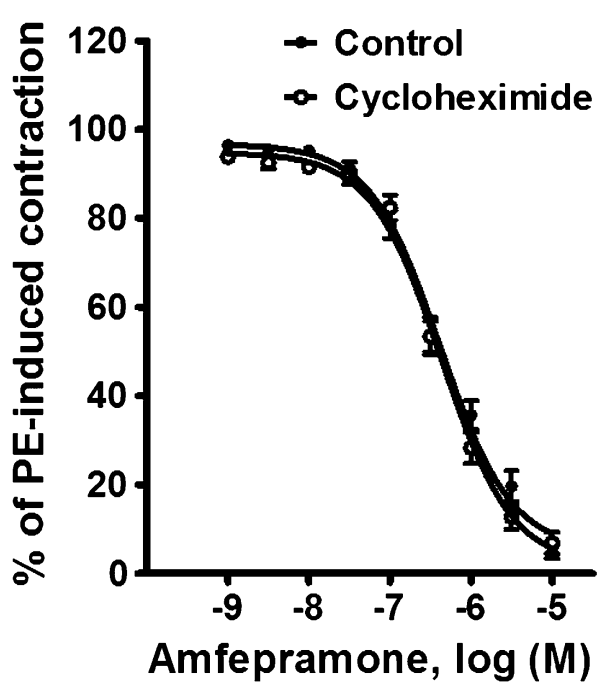

Figure 6. Effects of $10^{-5} \mathrm{M}$ cycloheximide on amfepramoneinduced vasorelaxation in rat aortic rings with functional endothelium and precontracted with $10^{-6} \mathrm{M}$ phenylephrine (PE). Data are reported as means \pm SE of $n=6$ observations. $P>0.05$ vs control (two-way repeated-measures ANOVA).

amfepramone has been associated with systemic vasopressor responses in dogs (13), and iii) our in vitro studies show that the direct application of amfepramone on rat aortic rings produced vasorelaxant effects in the rings with an intact endothelium. Overall, this evidence suggests, but does not categorically prove, that amfepramone could produce direct relaxation in the systemic vasculature. However, its predominant effect, following systemic and central routes of administration, seems to be vasoconstriction, possibly through the stimulation of central mechanisms.

On the other hand, acetylcholine produces concentrationdependent vasorelaxation in rat aortic rings (16-18), and was used in this study as a positive control of vasorelaxation. Several reports have shown that atropine-sensitive muscarinic receptors are involved in this vasorelaxant response $(17,19,20)$.

\section{Effect of amfepramone and acetylcholine on} phenylephrine-precontracted rat aortic rings

Aortic segments were pretreated with phenylephrine 30 minutes before administration of amfepramone and acetylcholine because the latter compounds elicited moderate concentration-dependent vasorelaxation in the previous assay with rat aortic rings (Figure 1). Acetylcholine was used as a positive control of vasorelaxation. It should be pointed out that under our experimental conditions, phenylephrine enhanced the vasorelaxant responses produced by amfepramone and acetylcholine (Figure 2). That effect was previously reported in other in vitro studies of acetylcholine and other drugs with vasorelaxant effects $(17,21,22)$.

On the other hand, the fact that amfepramone and acetylcholine produced a concentration-dependent relaxation in phenylephrine-precontracted rat aortic rings with intact endothelium, but not after mechanical removal of this tissue (Figure 2), suggests that the vasorelaxant effects produced by these drugs are endothelium-dependent. This corroborates several reports suggesting that the endothelium plays an important role in the vasorelaxation produced by acetylcholine (23-25). Following the evidence-based conclusion that acetylcholine produces vasodilation though the stimulation of endothelium-dependent mechanisms, we decided to investigate whether the endothelium also participates in the vasorelaxant response produced by amfepramone.

\section{Involvement of muscarinic receptors in the} vasorelaxant response produced by amfepramone on phenylephrine-precontracted rat aortic rings

Atropine, an antagonist of muscarinic acetylcholine receptors (26), did not modify the direct vasorelaxation produced by amfepramone on rat aortic rings (Figure 3), which excludes the possible involvement of stimulation of muscarinic acetylcholine receptors in the vasodilator responses produced by amfepramone.

Involvement of the NO pathway and $\mathrm{K}^{+}$channels in the vasorelaxant effect produced by amfepramone on phenylephrine-precontracted rat aortic rings

The fact that the vasorelaxant response induced by amfepramone in rat aortic rings was unaffected $(P>0.05)$ by 4-AP, a voltage-activated $\mathrm{K}^{+}$channel blocker (27), and glibenclamide, an ATP-sensitive $\mathrm{K}^{+}$channel blocker (28), but was significantly $(P<0.05)$ attenuated by $L-N A M E$, a direct inhibitor of NOS (29) and TEA, a Ca ${ }^{2+}$-activated $\mathrm{K}^{+}$channel blocker and non-specific voltage-activated $\mathrm{K}^{+}$channel blocker (30), indicates the involvement of the release of NO by endothelium tissue and the activation by $\mathrm{Ca}^{2+}$ of $\mathrm{K}^{+}$ channels. This conclusion is supported by the fact that the mechanical removal of endothelium blocked the vasorelaxation produced by amfepramone and acetylcholine in phenylephrine-precontracted rat aortic rings, and by evidence that the $\mathrm{NO}$ pathway and $\mathrm{K}^{+}$channels are involved in the endothelial-mediated control of vascular tone $(24,31,32)$.

There is evidence suggesting that additional mechanisms are involved in endothelial control of vascular tone, such as prostacyclins $(33,34)$ and endothelium-derived hyperpolarizing factor (EDHF), a cytochrome P450-derived arachidonic acid metabolite (35-37). Nevertheless, the vasorelaxation produced by amfepramone was unaffected by indomethacin, a prostaglandin synthesis inhibitor (38), and by clotrimazole, a cytochrome P450 inhibitor $(37,39)$, thereby excluding the involvement of prostacyclins and EDHF in the endothelium-mediated vasodilation under the current experimental conditions.

On the other hand, the fact that the vasorelaxant response to amfepramone was not significantly $(P>0.05)$ different after preincubation with the distilled water vehicle indicates that vasorelaxation to amfepramone is highly reproducible. This excludes the possibility that attenuations produced by the 
above inhibitors/blockers are tachyphylactic. Moreover, the fact that TEA, but not 4-AP, significantly $(P<0.05)$ attenuated the vasorelaxant response induced by amfepramone suggests the involvement of $\mathrm{Ca}^{2+}$-activated $\mathrm{K}^{+}$channels and excludes the involvement of voltage-activated $\mathrm{K}^{+}$channels. Admittedly, additional experiments that go beyond the scope of the present study will be required to further identify the specific subtype of $\mathrm{Ca}^{2+}$-activated $\mathrm{K}^{+}$channels involved in the vasorelaxant effects produced by amfepramone.

Involvement of protein-synthesis in the vasorelaxant response produced by amfepramone on phenylephrine-precontracted rat aortic rings

Cycloheximide, a general protein synthesis inhibitor (40), did not modify the direct vasorelaxation produced by

\section{References}

1. Delaet D, Schauer D. Obesity in adults. Clin Evid (Online) 2011; 2011.

2. Cheung BM. Drug treatment for obesity in the post-sibutramine era. Drug Saf 2011; 34: 641-650, doi: 10.2165/11592040000000000-00000.

3. Alemany M, Remesar X, Fernandez-Lopez JA. Drug strategies for the treatment of obesity. IDrugs 2003; 6: 566-572.

4. Pagotto U, Vanuzzo D, Vicennati V, Pasquali R. [Pharmacological therapy of obesity]. G Ital Cardiol 2008; 9: 83S-93S.

5. Adams C, Cohen A. [Appetite suppressants and heart valve disorders]. Arch Mal Coeur Vaiss 1999; 92: 1213-1219.

6. Seghatol FF, Rigolin VH. Appetite suppressants and valvular heart disease. Curr Opin Cardiol 2002; 17: 486-492, doi: 10.1097/00001573-200209000-00007.

7. Skopp G, Jantos R. [Phentermine - a "weighty" or a dangerous substance?]. Arch Kriminol 2013; 231: 116-129.

8. Scheen AJ. Sibutramine on cardiovascular outcome. Diabetes Care 2011; 34 (Suppl 2): S114-S119, doi: 10.2337/dc11-s205.

9. An H, Sohn H, Chung S. Phentermine, sibutramine and affective disorders. Clin Psychopharmacol Neurosci 2013; 11: 7-12, doi: 10.9758/cpn.2013.11.1.7.

10. Abramowicz MJ, Van Haecke P, Demedts M, Delcroix M. Primary pulmonary hypertension after amfepramone (diethylpropion) with BMPR2 mutation. Eur Respir J 2003; 22: 560-562, doi: 10.1183/09031936.03.00095303.

11. Crols R, Dierckx R, Saerens J, De Deyn PP. Transient ischemic attacks associated with amfepramone therapy: a case report. Funct Neurol 1993; 8: 351-354.

12. Abdallah AH, Roby DM. Effect of $\left(3^{\prime}, 4^{\prime}\right.$-dichloro-2(2-imidazolin-2-yl-thio)-acetophenone hydrobromide) (DITA) on pulmonary and systemic arterial blood pressure: a comparison with diethylpropion. J Pharm Pharmacol 1977; 29: 318-319, doi: 10.1111/j.2042-7158.1977.tb11325.x.

13. Safta L, Cuparencu B. Cardiovascular effects of amphepramone. Physiologie 1978; 15: 117-125.

14. Bispo Da Silva LB, Cordellini S. Effects of diethylpropion treatment and withdrawal on aorta reactivity, endothelial factors and rat behavior. Toxicol Appl Pharmacol 2003; 190: 170-176, doi: 10.1016/S0041-008X(03)00160-1.

15. Steel RGD, Torrie JH. Principles and procedures of statistic: a biomedical approach. New York: McGraw-Hill; 1997. amfepramone on rat aortic rings (Figure 6), which excludes the possible involvement of protein synthesis in the vasorelaxant effect produced by this appetite-suppressant drug.

In conclusion, our results suggest that the vasorelaxant responses produced by amfepramone in phenylephrine-precontracted rat aortic rings involved the inhibition of eNOS and the opening of $\mathrm{Ca}^{2+}$. activated $\mathrm{K}^{+}$channels.

\section{Acknowledgments}

We would like to express our deep gratitude to ${ }^{\dagger} \mathrm{Dr}$. Carlos Castillo-Henkel for his unconditional friendship, professional guidance and life example.

16. Gilissen MJ, van de Merbel-de Wit LE, Star WM, Koster JF, Sluiter W. Effect of photodynamic therapy on the endothelium-dependent relaxation of isolated rat aortas. Cancer Res 1993; 53: 2548-2552.

17. Zou Q, Leung SW, Vanhoutte PM. Activation of nicotinic receptors can contribute to endothelium-dependent relaxations to acetylcholine in the rat aorta. J Pharmacol Exp Ther 2012; 341: 756-763, doi: 10.1124/jpet.112.192229.

18. Luscher TF, Vanhoutte PM. Endothelium-dependent contractions to acetylcholine in the aorta of the spontaneously hypertensive rat. Hypertension 1986; 8: 344-348, doi: 10.1161/01.HYP.8.4.344.

19. Boulanger CM, Morrison KJ, Vanhoutte PM. Mediation by M3-muscarinic receptors of both endothelium-dependent contraction and relaxation to acetylcholine in the aorta of the spontaneously hypertensive rat. $\mathrm{Br} J$ Pharmacol 1994; 112: 519-524, doi: 10.1111/j.1476-5381.1994.tb13104.x.

20. Gericke A, Sniatecki JJ, Mayer VG, Goloborodko E, Patzak $A$, Wess $\mathrm{J}$, et al. Role of M1, M3, and M5 muscarinic acetylcholine receptors in cholinergic dilation of small arteries studied with gene-targeted mice. Am J Physiol Heart Circ Physiol 2011; 300: H1602-H1608, doi: 10.1152/ ajpheart.00982.2010.

21. Lopez-Canales JS, Lopez-Sanchez P, Perez-Alvarez VM, Wens-Flores I, Polanco AC, Castillo-Henkel E, et al. The methyl ester of rosuvastatin elicited an endotheliumindependent and 3-hydroxy-3-methylglutaryl coenzyme A reductase-independent relaxant effect in rat aorta. Braz $J$ Med Biol Res 2011; 44: 438-444, doi: 10.1590/S0100879X2011007500032.

22. Salahdeen HM, Idowu GO, Murtala BA. Endotheliumdependent and independent vasorelaxant effects of aqueous extract of Tridax procumbens Lin. leaf in rat aortic rings. Indian J Exp Biol 2012; 50: 883-888.

23. Furchgott RF, Zawadzki JV. The obligatory role of endothelial cells in the relaxation of arterial smooth muscle by acetylcholine. Nature 1980; 288: 373-376, doi: 10.1038/288373a0.

24. Furchgott RF. The role of endothelium in the responses of vascular smooth muscle to drugs. Annu Rev Pharmacol Toxicol 1984; 24: 175-197, doi: 10.1146/annurev.pa.24 040184.001135 . 
25. Furchgott RF. Role of endothelium in responses of vascular smooth muscle. Circ Res 1983; 53: 557-573, doi: 10.1161/ 01.RES.53.5.557.

26. Cuthbert AW. Some effects of atropine on smooth muscle. Br J Pharmacol Chemother 1963; 21: 285-294, doi: 10.1111/ j.1476-5381.1963.tb01527.x.

27. Shieh CC, Kirsch GE. Mutational analysis of ion conduction and drug binding sites in the inner mouth of voltage-gated $\mathrm{K}^{+}$channels. Biophys J 1994; 67: 2316-2325, doi: 10.1016/ S0006-3495(94)80718-0.

28. Schmid-Antomarchi H, De Weille J, Fosset M, Lazdunski M. The antidiabetic sulfonylurea glibenclamide is a potent blocker of the ATP-modulated $\mathrm{K}+$ channel in insulin secreting cells. Biochem Biophys Res Commun 1987; 146: 21-25, doi: 10.1016/0006-291X(87)90684-X.

29. Palacios M, Knowles RG, Palmer RM, Moncada S. Nitric oxide from L-arginine stimulates the soluble guanylate cyclase in adrenal glands. Biochem Biophys Res Commun 1989; 165: 802-809, doi: 10.1016/S0006-291X(89)80037-3.

30. Mathie A, Wooltorton JR, Watkins CS. Voltage-activated potassium channels in mammalian neurons and their block by novel pharmacological agents. Gen Pharmacol 1998; 30: 13-24, doi: 10.1016/S0306-3623(97)00034-7.

31. Adeagbo AS, Malik KU. Endothelium-dependent and BRL 34915-induced vasodilatation in rat isolated perfused mesenteric arteries: role of $\mathrm{G}$-proteins, $\mathrm{K}^{+}$and calcium channels. Br J Pharmacol 1990; 100: 427-434, doi: 10.1111/ j.1476-5381.1990.tb15823.x.

32. Furchgott RF, Cherry PD, Zawadzki JV, Jothianandan D. Endothelial cells as mediators of vasodilation of arteries.
J Cardiovasc Pharmacol 1984; 6 (Suppl 2): S336-S343, doi: 10.1097/00005344-198406002-00008.

33. Dusting GJ, Moncada S, Mullane KM, Vane JR. Implications of prostacyclin generation for modulation of vascular tone. Clin Sci Mol Med Suppl 1978; 4: 195s-198s.

34. Chapleau CE, White RP. Effects of prostacyclin on the canine isolated basilar artery. Prostaglandins 1979; 17: 573580, doi: 10.1016/0090-6980(79)90008-X.

35. Chen G, Suzuki H, Weston AH. Acetylcholine releases endothelium-derived hyperpolarizing factor and EDRF from rat blood vessels. Br J Pharmacol 1988; 95: 1165-1174, doi: 10.1111/j.1476-5381.1988.tb11752.x.

36. Komori K, Vanhoutte PM. Endothelium-derived hyperpolarizing factor. Blood Vessels 1990; 27: 238-245.

37. Hecker M, Bara AT, Bauersachs J, Busse R. Characterization of endothelium-derived hyperpolarizing factor as a cytochrome P450-derived arachidonic acid metabolite in mammals. J Physiol 1994; 481 (Part 2): 407-414, doi: 10.1113/jphysiol. 1994.sp020449.

38. Vane JR. Inhibition of prostaglandin synthesis as a mechanism of action for aspirin-like drugs. Nat New Biol 1971; 231: 232-235, doi: 10.1038/newbio231232a0.

39. Berhane Y, Bailey SR, Putignano C, Elliott J. Characterization of agonist-induced endothelium-dependent vasodilatory responses in the vascular bed of the equine digit. $J$ Vet Pharmacol Ther 2008; 31: 1-8.

40. Satav JG, Katyare SS, Fatterparker P, Sreenivasan A. Study of protein synthesis in rat liver mitochondria use of cycloheximide. Eur J Biochem 1977; 73: 287-296, doi: 10.1111/j.14321033.1977.tb11318.x. 